\title{
Sustainable management of wild Irish Atlantic salmon: Keys found through the looking-glass
}

Ruth E. Brennan, Lynda D. Rodwell

School of Earth, Ocean and Environmental Sciences, University of Plymouth, Drake Circus, Plymouth, Devon PL4 8AA, UK

\section{Abstract}

The recent moratorium on the commercial at-sea driftnet fishery for wild Irish Atlantic salmon (Salmo salar L.) attempts to halt the decline witnessed in these stocks over the past three decades. The research investigated stakeholder attitudes to the perceived effects on stock recovery, in Irish rivers and estuaries, of seal predation and seal culling. Structured interviews conducted with 10 key stakeholders during June 2007 revealed divisive attitudes and a feeling of powerlessness in relation to stock recovery, which are impeding successful management of salmon stocks. However, areas of common ground exist between stakeholders, which lay the foundation for a sustainable way forward.

This is the accepted manuscript of a paper originally published in Marine Policy. You may find the final, formatted version at 10.1016/j.marpol.2008.03.007.

And sure it is yet a most beautifull and sweete countrey as any is under heaven, being stored throughout with many goodly rivers, replenished with all sorts of fish most abundantly, sprinkled with many very sweete islands and goodly lakes, like little inland seas, that will even carry shippes upon their waters. Spenser's State of Ireland (1596).

\section{Introduction}

Spenser [1] would hardly recognise the "goodly rivers" of Ireland today. Irish Atlantic salmon stocks have declined by more than two thirds in the past 30 years [2] despite conservation measures introduced over the past decade. While it is generally accepted that the cause of the decline cannot be attributed to any one factor, there is also considerable consensus that a significant cause of the decline has been over-fishing by the government-subsidised at-sea driftnet fishing fleet. In 2005, this fleet accounted for approximately $68 \%$ of the national salmon catch, compared to $20 \%$ in the 1960 s [2]. Since the end of 2006, the Irish government has, in accordance with the scientific advice of the Standing Scientific Committee of the National Salmon Commission (the statutory body which advises on management of the national salmon resource), imposed a moratorium on the commercial at-sea driftnet fishery along with restrictions on estuarine driftnetting, draftnetting, snapnetting and angling in rivers where salmon breeding population levels are dangerously low. 
The wild Irish Atlantic salmon has long been embedded in Irish mythology as the brada' $n$ feasa (salmon of knowledge) [3]. The relationship between seals and humans is similarly instilled deep in Irish culture. Seal-lore traces the ancestry of certain Irish families back to unions between humans and seals (the enchanted people) and tells stories of seals rewarding human kindness and avenging ill treatment $[4,5]$. Irish nature conservation obligations apply to both seals and salmon: the EU Habitats Directive, ${ }^{1}$ implemented in Ireland by the European Communities (Natural Habitats) Regulations ${ }^{2} 1997$, lists both grey and harbour seals (Halichoerus grypus and Phoca vitulina), and (in respect of its freshwater habitat) the Atlantic salmon (Salmo salar L.), as protected species. Seals are also protected under the Wildlife Act 1976 which makes it an offence to hunt or injure seals, or to wilfully interfere with their breeding place.

${ }^{1}$ Council Directive 92/43/EEC on the Conservation of Natural Habitats and of Wild Flora and Fauna.

${ }^{2}$ S.I. No. 94 of 1997.

As the hunters (human and seal) find themselves converging on a shrinking target, the initial aim of this research was to investigate the ecological conflict resulting from the perceived direct effects of predation by, and culling of, grey and harbour seals on recovering Atlantic salmon stocks in Irish rivers and estuaries by examining the attitudes of certain stakeholder groups to the perceived effects on such stocks of seal predation and seal culling. The emergence of insights into the hidden needs of those stakeholders lends credence to Lavigne's view that the culling debate touches upon people's values and runs far deeper than science [6].

This article starts by providing an overview of the culling debate in the scientific literature (Section 2) followed by a brief description of the methods used by the researcher (Section 3). Section 4 describes the results of the investigation and probes more deeply into the underlying needs of the stakeholder groups which have emerged. The discussion examines how the feeling of powerlessness, experienced by stakeholders in relation to the depleted salmon stocks, impedes successful management of the national salmon resource and considers potential areas of common ground upon which the foundation for a sustainable way forward can be built.

\section{To cull or not to cull?}

This section examines a trend that has emerged in the scientific literature, particularly over the past two decades, towards the view that the culling of marine predators does not benefit commercial fisheries. However, the shortcomings of the various simplified foodweb models used to predict complex predator-prey interactions in the response to a cull are a major impediment to the progress of science in this area.

Myers et al. modelled a variety of depleted Canadian east coast fish stocks to investigate whether the cause of the decline of cod stocks could be attributed to depensation (where per capita rate of population increase is reduced when population size is low) and concluded that, in general, predators play no discernible role in the population dynamics of recovering fish stocks [7]. However, the limits of science are highlighted by the authors themselves noting that depensatory dynamics may arise by multispecies interactions and that shortcomings in their 
model may mask more complex behaviour. Using a single-species model, Mohn and Bowen found that grey seals were not a major factor in the collapse of cod stocks on the eastern Scotian Shelf, Canada [8]. A more complex (three species) model used by Punt and Butterworth to investigate whether South African cape fur seals were depleting the hake stock revealed that the seals were involved in a complex foodweb which might actually be increasing hake production in the fishery [9]. Building on this three species model, Yodzis used an extended foodweb model of the Benguela Current ecosystem to investigate indirect interactions (such as the effects on hakes of fur seal predation on other fish species) from changing seal numbers, and to see if valid conclusions could be reached from using only a subset of species in the entire foodweb [10]. While Yodzis concluded that "a cull is more likely to be detrimental than beneficial to the total fishery" [10], McLaren et al. point out that his results also embody a substantial probability that a cull of fur seals could have a positive effect on the fishery [11]. Yet, at a later point, McLaren et al. acknowledge that "ongoing research to place seal predation in an ecosystem context is unlikely, at least in the near future, to give definitive answers on the longer-term consequences of managing seal populations for the benefit of fisheries" [11]. Recognising that multi-species modelling is still very much in its infancy, Yodzis suggests applying several different modelling approaches to a particular system rather than relying exclusively on any one model for a prediction [10]. Yodzis also draws attention to the possible effects of global-scale environmental shifts (such as El Niño) on predator-prey and fishery regimes which could raise even more uncertainty about the application of complex ecosystem models to particular situations [12].

It is interesting to note the contrast between the focus of later literature (e.g. Myers et al. [7] and Mohn and Bowen [8]) on complex biological interactions and Gulland's emphasis on economic costs and benefits: "The balance might still be close in the case of harbour seals, but for grey seals the economic benefits to the fisheries of a cull would appear to greatly exceed the economic costs" [13]. While there is some recent evidence of a continued tendency to emphasise the economics (see McLaren et al. [11]), Yodzis comments that "... there is a considerable body of current opinion that fisheries should be managed in such a way as to avoid harm to natural populations rather than the other way around" [10]. While Yodzis' opinion arises more from ethical (rather than scientific) considerations [6], this in itself highlights the complexity of the subject. The question of whether to cull or not to cull involves a fact/value conflict where there is lack of agreement over both facts (as illustrated by the scientific debate above) and values (socio-economic vs. ecological/ethical objectives) [6]. Lavigne takes the view that, as modern society does not have a mechanism for resolving such cultural disputes, the only hope for resolution is that over time, some agreement can be reached, either on the facts or values or both, thereby moving the conflict into an arena where conflict resolution mechanisms do exist (through legal, scientific and/or political means) [6].

In summary, therefore, while there is increasing support for the view that "[t]here is no scientific evidence that the culling of large marine predators has ever benefited a commercial fishery" [14], the robustness of the evidence that culling does not benefit a commercial fishery is not beyond challenge, not least because of the inadequacies of foodweb models. Recognition of such inadequacies has led to a growing consensus that the complexity of predator-prey 
relationships in the context of the tangled nature of aquatic foodwebs may be too dense ever to unravel completely [10].

\section{Methods}

\subsection{Research design}

A narrative approach was applied to this preliminary investigation of values and perceptions, because of their personal nature and because story-telling is an important part of Irish culture. This qualitative research method focuses on how individuals assign meanings to their experiences through the stories they tell [15] and is the starting point for the linkage of "personal troubles" and "public issues" [16].

\subsection{Interview process and data analysis}

Ten semi-structured, face-to-face interviews were conducted with respondents in a variety of locations around Ireland (Fig. 1). The target stakeholder groups were identified as those with the potential for direct (hands-on) contact with seals and/or salmon in Irish rivers, estuaries or at sea. The respondents (Table 1) represented former commercial at-sea driftnet fishermen, commercial estuarine driftnet and draftnet fishermen, traditional (snapnet) fishermen, anglers, wildlife conservationists and the National Parks and Wildlife Service (responsible for hands-on management of Irish nature conservation).

Given the preliminary nature of this research, exploratory interviews were conducted. The interviews, which were audio-recorded, were structured around seven open-ended interview questions to allow the respondents to talk freely, underpinned by more specific probing questions. This structure was designed to reduce interviewer bias, which is a potential problem with this type of research. The audio-recordings, which were subsequently transcribed, yielded a "rich store of attitudinal and perceptual expressions" [17]. The data was analysed using a framework analysis approach [18] which consisted of summarising the main themes and subthemes which emerged from the interviews into a coherent series of theme tables. The limited number of respondents interviewed means that the sample is not representative. However, the aim of the interviews was "not data collection but ideas collection" [17].

\section{Results and discussion}

\subsection{Overview}

This exploratory research into stakeholder attitudes to the impact of seal predation and culling on wild Irish Atlantic salmon has borne out Lavigne's observation that "... the debate over culling marine mammals ... has more to do with values, attitudes, and societal objectives, and therefore politics, than it has to do with science per se" [6]. The investigation of these attitudes has elucidated certain core values and underlying needs of stakeholders directly affected by the demise of wild Irish Atlantic salmon stocks and has revealed how the complexities of a delicate and sensitive natural resource management situation have been exacerbated by perceived political machinations. The reactions and attitudes to the government-imposed moratorium on the commercial at-sea driftnet fishery and the restrictions on estuarine driftnetting, 
draftnetting, snapnetting and angling in rivers where salmon breeding population levels are dangerously low, illustrate how cultural disputes cannot be resolved through

purely legal, scientific and/or political means. It is suggested that the way forward through this apparent impasse is to focus and build upon the tangible areas of common ground that have also been revealed by this preliminary research. An essential part of this building process must be to harness the more intangible sense of hope that can, at times, be glimpsed in spite of the overwhelming feeling of powerlessness conveyed by all of the respondents. By examining the results of the investigation of stakeholder attitudes to the effect of seal predation and culling on wild Irish Atlantic salmon, this section highlights the more fundamental underlying stakeholder needs that have been revealed and discusses the implications of the existence of such needs. ${ }^{3}$

${ }^{3}$ Direct quotations have been used in this section to convey the respondents' natural mode of expression. Explanatory footnotes have been added to avoid confusion which may arise from certain phrasings (often the result of a direct translation from the Irish to the English language).

\subsection{Seal predation}

The general consensus amongst the respondents was that seal predation in itself had contributed very little, if at all, to the decline in wild Atlantic salmon stocks. There were a number of variations on this general view. Several respondents felt that the effect of seal predation on salmon stocks had been exacerbated and/or magnified by the presence of driftnets at sea, described variously as "the provision to the seal of food in a dish" (Angler A), an "easy meal" (Angler B), a "buffet" (Conservationist A) and a "free meal" (Conservationist C). Driftnet and Draftnet Fisherman B went so far as to say that if the salmon were not "stuck in the nets", the seals "wouldn't bother, they wouldn't have as good a chance at catching them". This was echoed by Angler A's observation that "... the sporting chance of a salmon to get away from a seal is natural", Angler B: "... I personally don't believe that a ... seal could catch a salmon in the sea ..." and Conservationist C: "... what amazes me is that they can actually catch a salmon ...". Another variation on the theme was evident from the views of most of the driftnet and draftnet fishermen on the existence of other predators for salmon. Thus, for example, Driftnet and Draftnet Fisherman B thought that while "... the seals were bad outside for the driftnetting ... I think myself that, you know the dolphins now and the porpoises, that they'd eat the salmon as well ...". These varied views reflect the continued uncertainty of the science in the area of complex predator-prey interactions (see Section 2). There was, however, one minority voice amidst all of the above. Driftnet Fisherman C bemoaned "[t]oo many seals, too many seals, too many seals ... we had to go in oft because ... every salmon that was in the net, there was so much seals, they were taking it". An interesting juxtaposition on this latter view was offered by the perception of Driftnet Fisherman A that "... in the end of the day, the seal probably has saved salmon more than anything else" on the basis that "... if I was out fishing and I had 20 fish in the net and there's a few seals around and they took 10 fish ... it wouldn't be worth my while, I'd say: " $F$ " this, I'm coming in ... So then, what the seal is after doing is it's after ${ }^{4}$ putting nets out of the way so the salmon get through ...". In a similar vein, 
Conservationist A describes seals as "the ultimate and most sophisticated fisheries managers ... what's left for us is the prime fish" as "[t]hey, like any predator, pick out the weak ...".

${ }^{4}$ In the phrase "what the seal is after doing is it's after putting nets out of the way", the use of the word "after" denotes the past tense. Thus, the literal meaning of the phrase is: ... what the seal has done, is that it has put nets out of the way...

It is suggested that Driftnet Fisherman C's contrasting perception of the effect of seal predation is because he sees seals as a threat to the most basic need in his community of food on a plate: “... people can't fish any more for their dinner, because there's too much seals there ... if you go out ... handlining, they would take all the pollack off your handline ..." Acknowledgment by other stakeholders of this very real fear, which runs far deeper than a mere threat to livelihood, is essential to cultivating a more realistic perspective of the effect of seal predation on salmon stocks. Arguably, the recognition by Bord lascaigh Mhara (the Irish Sea Fisheries Board) of "the strong perception in fishing communities that seals may have a significant impact on stocks of certain fish, including salmon" [19] is limited to a recognition of a threat to livelihood. It is significant that despite his perception of the effects of seal predation, Fisherman $\mathrm{C}$ seemed at a loss as to how to explain the demise of wild salmon in general: "... the government never made nothing to find out about ... the salmon". This uncertainty appeared to further magnify the effect of seal predation on salmon for Fisherman C.

\subsection{Seal culling}

The vast majority of respondents were reluctant to support a general seal cull, for a variety of reasons. Several of the fishermen and conservationists alike queried how a cull could be quantified and measured: "... how many salmon is the seals catching [?]" (Driftnet Fisherman C); "... how do you quantify and measure ...[?]" (Conservationist C). The overall feeling of these respondents was reflected in the comment of Draftnet Fisherman A when he said "I'm definitely not going to sign the death knell for the seal, that I don't know nothing about ...", reflecting Montevecchi's observation on the lack of scientific evidence as to the benefits of a cull for a commercial fishery [14]. The pointlessness of a cull now that the at-sea driftnets have been removed was also flagged. Angler A noted the irony of the fact that while the driftnet moratorium did away with any need for a cull, "the balance will be that there will be a natural cull as a result of it", echoing Conservationist A's observation that "[c]ontrary to popular belief, the food source controls the predator population rather than the other way around ...". Yet again, a minority voice was evident (though interestingly, not the voice of the fisherman who felt most aggrieved by seal predation) that "[d]efinitely the seal should be culled ...". This contention by Driftnet and Draftnet Fisherman B lies in stark contrast to his later musing that “... the driftnetting is stopped now, they mightn't have that big effect on it now when the fish wouldn't be getting stuck in the nets ...". The contrasting viewpoints from the same voice here perhaps reveal an automatic adherence to a familiar position or belief without reflection as to whether that position is justifiable or even necessary anymore. Support for this interpretation is provided by the fact that Fisherman B's definitive assertion was not proffered in response to a direct question about seal culling. Rather it was mentioned, almost as an aside, while talking about the detrimental effect of dolphins, porpoises and pollution on salmon. 


\subsection{Perceived causes of salmon stock decline}

A wide variety of main causes for the salmon stock decline was highlighted by the 10 respondents, namely, driftnetting, intensity of fishing effort/over-fishing, water pollution/habitat damage, hatcheries, fish-farming, predation and political corruption. The vast majority of respondents $(80 \%)$ cited three or more causes while the remaining two respondents each homed in on one particular cause, pollution in one case and the lack of hatcheries in the other.

Conflicting opinions emerged on the subject of hatchery-raised salmon, revealing different perceptions of what, in fact, constitutes a "wild salmon". Driftnet Fisherman A felt strongly that the high proportion of hatchery-raised, as opposed to wild, salmon was the primary cause of the decline of salmon stocks: "... the genetics of the fish are all topsy-turvy because you have ranched fish that have interbred ... the smolts that are going to sea now are heading for $100 \%$ hatchery fish. Before they reach the mouth of the river, there's half of them dead"'. This view is diametrically opposed to the views of Draftnet Fisherman A who was adamant that the main cause of salmon stock decline was "the fact that there's no hatchery being put in ..." on the basis that "... without the hatchery ... the salmon can't actually survive ...". Interestingly, both of these views conflict with the views of the relevant scientists. Draftnet Fisherman A notes that “... they'retelling us ... that it can survive on the natural spawning ... which we know personally it can' $t$ " while Driftnet Fisherman A points out that, up to very recently, "the scientists said: oh no no, the proportion of wild fish to hatchery fish ... there's no problem with the wild fish".

This is a striking example of the quagmire that can result from different views of reality and highlights an urgent need for multi-stakeholder dialogue to develop a shared understanding of reality. Such a shared understanding, however slim, would provide at least some common ground upon which to base acceptable decisions regarding hatcheries. Even more striking, however, are the political conspiracy theories underlying these views. Thus, Driftnet Fisherman A goes on to say “... one of the same guys only less than 4 months ago ... said, 'I don't believe ... there are any wild fish ... in the Shannon system' ... you see they've come to admit it all now ... because the politicians don't need them to say: the wild fish are there, let the people fish on ...", while Draftnet Fisherman A feels that "... they have been downgrading the fishing ... the fishermen feel ... just to get rid of mostly everybody first, and then when everybody is gone, come back and do it up for their own ... gain ..." These perceptions of political machinations, along with Driftnet Fisherman C's exaggerated perception of the effect of seal predation on salmon stocks (Section 4.2) and Driftnet and Draftnet Fisherman B's knee-jerk-like assertion of the need for a seal cull (Section 4.3), hint at the existence of far more fundamental matters underlying the surface issues investigated.

\subsection{From powerlessness to trench-warfare}

Without exception, the respondents' attitudes to the decline and current state of wild Irish Atlantic salmon stocks were characterised by an overwhelming feeling of powerlessness about the situation. This strongly suggests that the national salmon resource is not being co-managed 
by all relevant user groups. Jentoft observes that "empowerment is what co-management is all about, as it involves bringing previously excluded, disenfranchised and sometimes alienated user groups and stakeholders into the management decision-making process, by reshuffling power and responsibility among those who form the fisheries management chain" [20]. The respondents' various observations belie feelings of alienation, dispossession and disempowerment: "... they're squeezing us out is the way we feel ... they have pushed ... the ordinary guy aside ..." (Draftnet Fisherman A); "... they took away the stocks. Now they've come along and put us off ..." (Snapnet Fisherman); "[t]hey introduced the tagging system in 2002 ... over our heads ..." (Angler A); "the politicians ... didn't protect the little fellas at all ..." (Conservationist B). In a similar vein, one of the angler members of the Sea Fishery Advisory Group of the Irish Seal Sanctuary recently wrote: "when I attended my first R.A.C. meeting I realised that we were up against a real problem. We were an assortment of ex-fishermen, anglers and a salmon netsman and lined up against us were a set of 'men in suits"' [21].

Jentoft goes on to describe an empowered person as "one who has the ability to understand the forces that are impacting on himself or herself, who can analyze a social and political context critically, and who knows how to act in situations that demand a response" [20]. Respondents' descriptions of stakeholder responses (past, present and expected future) to the decline in salmon stocks reveal how far from empowerment they feel: "... if ... you're getting your livelihood eroded away bit by bit by bit ... you're going to want to take action ... that's a natural reaction" (Conservationist $\mathrm{C}$ ); “... they just took the guns into their boats and went out and held up the Fishery Patrol ..." (Angler A); "... they're going to go poaching ... to put ... pressure on the government ... just to ... see would they see sense ..." (Driftnet Fisherman A); "... there'll be more people out there putting out nets ... they don't care about the salmon ..." (Driftnet Fisherman C); "... there is netting at sea going on at the moment ... The Fishery Board know about it ..." (Angler B). These comments also point to a distinct lack of honesty in dealings between the government and fishermen.

It would seem that the decline and "management" of the national salmon resource has, on one level, degenerated into a polarised struggle for control, between the stakeholder groups (represented by the respondents) on the one hand and the powers-that-be (perceived as the government and the scientists) on the other. Thus, Draftnet Fisherman A admits that "... what we're afraid of is ... the powers-that-be ... the government at the moment, they basically, they want to ... privatise it, they want to turn it into ... salmon ranching ... so what they actually want to do is control the whole situation themselves ...", a view that is echoed by Angler A: “... Fishery Board managers want to take over for themselves and charge anglers a daily rate ... they see this as a revenue-generating scheme ...". There is a palpable sense of distrust of government motives, bluntly described by Draftnet Fisherman A "to get rid of mostly everybody first, and then when everybody is gone, come back and do it up for their own ... gain ...". Significantly, Draftnet Fisherman A in the same breath juxtaposes seal culling with putting the fishermen off the river: "if they get rid of the seals, if you get rid of us ...". Seen in this context, Draftnet Fisherman A's earlier comment that "there should be room for everybody there", in relation to seal predation and seal culling, is quite poignant, taking on the character of a plea to leave room for the ordinary fisherman. 
The reference to strong symbols, the drawing of vivid analogies and the use of battleground language by several respondents supports the view that entrenched positions have been identified, often within each stakeholder group, and are being vigorously defended in the context of the management of the national salmon resource. Draftnet Fisherman A observes "... they have banned it here and there, they have actually divided up the fishermen ... divide and conquer as they say". This is echoed by Driftnet Fisherman A: "Fishermen no longer exist ... as an entity ... the owners of the boats are not aboard the ships at all ...". Two respondents drew parallels with the situation in Northern Ireland: “... it's a bit ... like the Northern Ireland peace process ..." (Conservationist A); "... it is like the, the old scene up North a bit you know, they did it from tradition, the guarding of the tradition is what they're about ..." (Angler A). Snapnet Fisherman preferred the Italian motif: "... they'll give them a golden handshake now and then allow them back out to fish again ...'tis like a mafia now for all in the world ...'. These descriptions reveal that the different stakeholder groups are not always unified against the government. On this level therefore, the struggle to manage the national salmon resource is not polarised; it is, even more unhelpfully, factious. Such division within the ranks can only enhance the sense of powerlessness felt in the face of the powers-that-be.

The above discussion highlights a fundamental need for empowerment on the part of the stakeholder groups represented by the respondents as "a way out of helplessness and hopelessness in socio-political struggle" [20]. While distrust of the government is clearly present as illustrated by the various conspiracy theories, the need for the government to play an active role in the management of the salmon resource is generally accepted, as expressed by Draftnet Fisherman A: “... the way the fishing has been the last 10 years, somebody needed to take control of it ... But ... it has to be distributed evenly for everybody ... it shouldn't be the way that you cut out one section of the industry just to have it for somebody else there ...".

\subsection{An informational mine-field}

The hatcheries quagmire, discussed in Section 4.4 above, provides an insight into another underlying need of the respondents and the stakeholder groups they represent: the need to be listened to. Draftnet Fisherman A comments: “... a lot of these guys ... they'd want to ... come out of their ... offices doing all these surveys and things, they' $d$ actually want to ${ }^{5}$ walk on the ground to see what's actually happening on the ground", revealing an opinion, echoed by several other respondents, that the scientists do not listen to the fishermen and are too far removed from what is happening to get it right.

${ }^{5}$ The phrase "they'd want to ... come out of their ... offices ... they'd actually want to walk on the ground" literally means "they ought to ... come out of their ... offices ... they actually ought to walk on the ground".

Draftnet Fisherman A's earlier reference to the need for hatcheries as "the old story" suggests that it has taken on the quality of an adage. Regardless of who is correct in relation to the hatcheries debate, these comments suggest the rigid adherence to a position (the need for hatcheries) by certain fishermen almost as an example of how they are not listened to by the scientists. If the management of the salmon resource involved taking on board these 
fishermen's cardinal concern (which is that salmon cannot survive naturally), perhaps by "walking on the ground" with the fishermen, using counters to monitor salmon populations and sharing the results with the fishermen, it might go some way towards reducing the gap and distrust between these two groups. Indeed, the fishermen's hatchery conviction might even fall away as a result of this gap being bridged, as this conviction may well be, without them realising it, a front for their deeper need to feel that they are being listened to by the powersthat-be. A further insight into the gap between fisherman and scientists is revealed when Draftnet Fisherman A suggests a link between peak season pollution from a nearby milk factory with later salmon runs in his river: "well ... it's just a thought that has been striking our head of late like. I'm not, I don't, I don't think there's any scientific advice or anything there". He is almost apologetic for having the audacity to make a link which he seems to feel belongs to the scientific field of expertise. This reveals a shyness and timidity about fishermen's opinions beneath all the outward bluster and appearance of firmly believing in what they say. It could suggest that if such comments by fishermen were taken seriously and welcomed as intelligent and useful, fishermen might have more of an impetus to work with scientists rather than seeing themselves as in opposition to them.

In the context of whether a seal cull would be necessary to assist the recovery of salmon stocks, respondents' views varied on the source of information on which management of the salmon resource should be based. Some respondents felt that fishermen would have better insights than the scientists, reflected in Driftnet and Draftnet Fisherman B's comment: "I'd trust more ... from the fishermen ... because ... the scientists wouldn't have the experience of seeing it ...". Others, such as Angler A, tended towards the need for "... proper scientific research ... credible scientific work ... independent sources". A majority of the respondents voiced the need for "the two of them together" (Driftnet Fisherman C), qualified by the need to know "how the data was gathered" (Angler B) in order to assess its accuracy and credibility. While many of the respondents pointed out that information from fishermen would be "biased ... towards their own livelihoods" (Angler B) and "personal and emotional" (Angler A), Driftnet Fisherman A introduced an added dimension by querying the independence of Irish scientists on the basis that the line is blurred between fishermen and scientists where the latter come from a fishing background: "... that line ... scientists and certain fishermen, is indistinguishable now ... because a poor fisherman was a poor fisherman before. ... the newer generations have been well-educated ... and they're scientists, you understand, so the family connection comes into it ...". Indeed, Driftnet Fisherman A goes further and suggests that the demise of the salmon stock was not solely due to the government ignoring scientific advice regarding catch limits, rather, it was as much due to the scientists providing politically acceptable rather than "scientific" advice: "it's not scientific science ... it's political science that the scientists are using, nothing else". Driftnet Fisherman A gives the River Feale as an example: "... the Feale ... [I] ast year ... got a quota of 1100 fish. They failed to catch the quota of 1100 fish. Now what is the quota for this year? It's 2800 ... double, nearly triple. ... that's a political decision ...".

Angler A tells a similar story when he describes how the conservation limits of rivers (the minimum amount of adult spawning fish needed to sustain a river's population [2]) are being recorded on the basis of clearly flawed information. In 2002, according to Angler A, "there was 
78 fish caught according to the Fishery Board records as against our 400, 450 fish ... They've now registered our river as catching 160 fish ... it's about 300 fish more we're catching ...". Yet, when the Federation of Irish Salmon and Sea Trout Anglers drew this to the attention of the Fisheries Boards, and offered them the information collected through the system already established within the angling club, in the form of a "mass club-return", the Fisheries Boards "said no ...". "[T]hey're not interested in actually co-operating with our data collection ..." concludes Angler A.

Overall, the consensus amongst the respondents was that the source of the information needed to be honest and independent and the information itself needed to be seen to be accurate. While these concerns were expressed in response to a question about seal culling, it is contended that they apply more generally to environmental resource management. Indeed, the impression given was that fishermen would accept "bad" news about the state of fish stocks and the need for stringent conservation measures if they received such information from an honest and independent source. Thus, the non-acceptance of scientific advice would seem to be very strongly linked to its source. If the source is perceived as tainted (e.g. through family connections, politics) the natural reaction of the fishermen is to resist what they perceive as an injustice, regardless of the accuracy of the data. As such, the non-acceptance by certain fishermen of conservation measures imposed ("... the commercial guys ... don't recognise that there was a recovery needed ..." (Angler A)) arguably masks the need for an honest and unbiased source of information and regulation. Perhaps this need could be met (at least in part) by bringing in independent observers as suggested by Driftnet Fisherman A when he tellingly described Orri Vigfusson, Chairman of the North Atlantic Salmon Fund, as having "no personal or family connections here in this country".

\subsection{Communication barricades}

"But how can you talk with a person if they always say the same thing?" asks Alice in the children's novel "Through the Looking-Glass" [22].

This insightful question brings to mind the almost automated repetition of familiar positions and beliefs by certain stakeholder groups and exemplifies the need for dialogue which allows stakeholders to move beyond their familiar territory into the world of the Looking-Glass House, where things look "as different as possible" [22]. Given the entrenched nature of these beliefs and positions, an independently facilitated dialogue (for example, in the form of facilitated workshops) is essential. The views of the "other side" do not always register when those views are transmitted by that "other side" rather than by an independent third party, as illustrated by Driftnet and Draftnet Fisherman B: "I asked that question ... at a meeting we had there last year there and ... the scientists, I don't know what answer did they give, they didn't give a satisfactory answer anyway ...".

"[W]e need to educate the fishermen ... to the fact that the source of fish ... is finite ... that it's a delicate balance ..." insists Driftnet Fisherman A, flagging the importance of education in opening up new channels of communication. Conservationist $A$ adds his voice to the call for education: “... you know people are doing something one day, and it's particularly evident in 
areas of primary production ... suddenly a law comes in that doesn't fit ... that's why I feel so much has to go into education, and headhunting people in those communities saying look it's time to change ... you're not going to change them by laws you know". This resonates strongly with Conservationist C's more general perception that "... you will not achieve conservation goals by ramming it down people's throats. If you don't bring them with you ... you are going absolutely nowhere ...". While these observations are important, the discussion in Section 4.6 indicates that scientists have much to learn from the fishermen. A "one-way" educational programme could actually fortify barriers to communication rather than dissolve them.

As discussed in Section 4.4, a wide variety of strong views on the different causes for the salmon stock decline emerged from speaking to merely a handful of stakeholders. This further highlights the need for independently facilitated workshops to openly discuss such causes, so that useful common ground can be identified and then built upon by including at least an investigation of such causes in the management of the resource. The strong emotions surrounding this subject suggest that unless all such "causes" are seen to be listened to, investigated and addressed, the various stakeholders will feel alienated and therefore disempowered, as they will not feel that they are part of the management solution. On that note, the title of angler Woodlock's article is telling: "Nobody asked me" [21].

Conservationist $\mathrm{C}$ and Angler $\mathrm{A}$ offer important insights in relation to the breaking down of communication barriers: "... I was able to talk to these guys because I was from North Mayo and I understood exactly where they were coming from. I know colleagues of mine ran into all sorts of trouble because of their accents or because of the way they looked" (Conservationist C); and "... what you do is you get a member that's a relation ... 90\% of the time it's ... that they're being approached the wrong way ... that's ... on the ground stuff, it takes the slower things ..." (Angler A). This latter comment echoes Jentoft's warning that as co-management is a gradual process, a certain degree of patience is needed and that empowerment "must be built gradually and progressively to be sustainable" [20].

\subsection{Seeds for co-management}

"In another moment Alice was through the glass ... she began looking about and noticed that what could be seen from the old room was quite common and uninteresting, but that all the rest was as different as possible" [22].

Conservationist C could have been commenting on Alice's journey to the Looking-Glass House when he observed (in relation to communicating with fishermen) that "it's all about perceptions". This is the crux of what has been revealed by the investigation of stakeholder attitudes to the effect of seal predation and seal culling on wild Irish Atlantic salmon stocks, highlighted by differing perceptions as to, for example, the need for, or damage caused by, hatcheries, and the role played by seals in safeguarding, or damaging, salmon stocks. In the light of such vastly different interpretations of the same reality, the need to build on whatever common ground exists between stakeholders at this point in time is crucial to successful comanagement, described by Jentoft as "... a process where all those involved gain, because they 
become better able to accomplish what they are capable of and thus realize what is in their common interest, i.e. securing the resource in a way that is profitable, equitable and just" [20].

In addition to the needs for empowerment and an independent and credible source of information discussed above, a major area of common ground identified by the respondents, without exception, was to see "the fishes being back" (Driftnet Fisherman A). Indeed, a large majority of the respondents hoped to see "the fishing industry still vibrant" (Angler B), with Conservationist A pointing out that "[n]obody wants to condemn salmon to a ... glass case type situation ...". On a practical level, Draftnet Fisherman A suggested going back to the more traditional and inefficient forms of fishing, for example by banning the use of monofilament nets throughout the industry in general. A conservationist approach has been put into practice by the angling community since 2001 when the Federation of Irish Salmon and Sea Trout Anglers asked the government to ban the sale of rod-caught fish on the basis that anglers wanted "to be seen as environmentalists committed to conservation" (Angler A). As a result, commercial angling no longer exists in Ireland.

The elusive quality of hope for the recovery of the salmon stocks, mentioned at the outset, was also a common theme amongst the respondents: "... it will rebuild, there's no doubt about that ... if 'tis done properly ... they're a magnificent fish ... They deserve to survive ..." (Snapnet Fisherman); "... it's a bit ... like the Northern Ireland peace process, you know, at the end of a long war, there is still the possibility of ... living together ..." (Conservationist A); "... the salmon have a way of protecting themselves ... I said in ... 9 or 10 year's time I said that the rivers would be teeming with fish again, And I firmly believe that ..." (Driftnet and Draftnet Fisherman B); "... to quite a lot of people ... it's a romantic dream but they still want to keep it alive" (Angler A). Indeed, such "romantic dreams" could perhaps offer a hitherto unrecognised area of common ground between scientists and fishermen, to draw from Conservationist A's observation that "real scientists are huge romantics...like I mean they have visions like getting to the moon! Or splitting the atom! ... they're really imaginative, creative people".

Staying with the notion of dreams, it is a child's natural sense of curiosity that prompts Alice to explore the Looking-Glass House. Perhaps it would be worth nurturing the curiosity of all stakeholders (including scientists) to encourage them to make the leap to viewing "the old room" from a different perspective? Snapnet Fisherman's observation that "the fun is gone out of it you know, everything's so serious now" suggests that this might well be worth exploring. A possible starting point could be to remind stakeholders of the rich repository of Irish myth and legend alluded to in Section 1. Referring to Irish seal traditions, Ni' Fhloinn comments that "the beliefs and stories can be seen to reflect an infinitely more refined and sophisticated understanding of the delicate balance which exists between mankind and the natural environment-and of man's place in the overall scheme of nature-than we find in what would usually be regarded as more advanced systems of belief. As such, the legends and beliefs still have much to offer us" [4]. 


\section{Conclusion}

"The only thing that one really knows about human nature is that it changes ... The systems that fail are those that rely on the permanency of human nature, and not on its growth and development. The error of Louis Xiv was that he thought human nature would always be the same. The result of his error was the French Revolution. It was an admirable result. All the results of the mistakes of governments are quite admirable" [23].

It would appear from this preliminary research that the government has made many mistakes in relation to the management of the national salmon resource. It is questionable whether the results of any of these mistakes can be described as admirable, other than in the sense that they may have allowed certain stakeholder groups to discover areas of common ground between themselves. Unfortunately, the divisive nature of the debate surrounding the management of wild Atlantic salmon has largely negated the value of these tufts of shared territory.

\subsection{The culling debate}

While it is often the case that when "a natural resource comes under pressure, the natural predator seems to be the scapegoat" (Conservationist A), this research shows that the debate around seal culling is only one of many threads in the tangled web of wild Irish Atlantic salmon stock management. Focussing on this element alone would therefore be of marginal utility to achieving the broader goal of sustainable management of the national salmon resource.

\subsection{Striking a management balance}

Although acceptance of the need for an active government role exists amongst stakeholders, a careful balance must be struck between local and central government management. Lane and McDonald observe that central government agencies and local communities act at different political scales so that "environmental management, policy and practice occur, at any moment, somewhere along a sliding (even slippery) scale that ranges from the local to the central" and warn that too much emphasis on particular stakeholder interests can exclude the general public interest from being taken into account [24].

\subsection{Empowerment entails responsibility}

"Fishing is an odd thing in that you will hear of boats called the Marine Harvest and Sea Reaper. They use farming terms all the time but never sow seed or look after their stock" [21]. The quid pro quo of empowerment and co-management must be the acceptance of responsibility by stakeholder groups to work towards a common goal. Empowerment "results from within the individual, for example, from gaining more experience and competence in participatory processes" [20]. The Federation of Irish Salmon and Sea-Trout Anglers have set a praiseworthy example by independently engaging in on-the-ground works to restore damaged spawning habitats. The question is whether initiatives such as this one can be reflected across all stakeholder groups, the government included, with everybody pulling in the same direction. Patience is undoubtedly an essential ingredient of any such process. 


\subsection{Policy recommendations}

The need for independent third party observers to be involved at, in particular, the central levels of the management of the salmon resource is crucial to dispelling perceptions of political machinations on the part of both the government and the scientists and to fostering a sense of trust within the management continuum, from local to central.

Interactive and participatory learning, as opposed to a one-way, lecture-based educational programme, would greatly enhance the flow of information, and the fostering of trust, respect and confidence, between the scientific and fishing communities in particular. Independently facilitated workshops are essential to ensure that all stakeholder groups have the opportunity to "tell their story", and to actively listen to the views of others.

The Fisheries Boards should accept the mass club-returns offered by the Federation of Irish Salmon and Sea-Trout Anglers for comparison with the information received via their own tagging system. A precautionary approach should then be adopted in the recording of conservation limits for the relevant rivers by assuming that more, rather than fewer, salmon have been caught. Failure to adopt such a precautionary approach gravely under- mines the ability of the Standing Scientific Committee of the National Salmon Commission to determine which rivers are scientifically above the relevant conservation limit, and hence which rivers should be open to fishing.

These policy recommendations are suggested as tentative first steps towards the more constructive co-management of a complex arena fraught with entrenched value judgements and deep-seated emotions. There is still time to manage (what is left of) the wild Irish Atlantic salmon stock in an effective and sustainable manner.

\section{Acknowledgments}

The corresponding author would like to thank supervisors Dr. Lynda Rodwell and Dr. Jo Richards (University of Plymouth) for their helpful comments on earlier drafts of this article. I also appreciate the support provided by Dr. Rona'n Long (National University of Ireland Galway) in making the facilities of the Marine Law and Ocean Policy Centre in Galway available to me for the duration of this research project. I acknowledge the funding provided by the School of Earth, Ocean and Environmental Sciences, University of Plymouth, to assist in the carrying out of this research. Finally, I am indebted to the participants in this research project for the richness of the data provided and am sincerely grateful for their time and interest.

\section{References}

[1] Spenser's State of Ireland, 1596. Cited in: Maxwell WH. Wild sports of the West interspersed with legendary tales and local sketches. London: Routledge; 1832.

[2] Standing Scientific Committee of the National Salmon Commission. The status of Irish Salmon stocks in 2005 and precautionary catch advice for 2006, 2006. Retrieved from /http://www.shannon-fishery-board.ie/guides/game/ reports2006/NSCCatchadvice.pdfS. 
[3] Gregory A. The coming of Finn. In: Lady Gregory's complete Irish mythology. London: Octopus Publishing Group Ltd; 1994. p. 117-23.

[4] N' Fhloinn B. Tadhg, Donncha and some of their relations: seals in Irish Oral Tradition. In: Lysaght P, O' Catha' in S, O' h O' ga' in, editors. Islanders and Water-Dwellers. Proceedings of the Celtic-Nordic-Baltic folklore symposium held at University College Dublin. 16-19 June 1996, p. 223-45.

[5] Thomson D. The people of the sea: Celtic tales of the seal-folk. Edinburgh: Canongate Books Ltd.; 2001.

[6] Lavigne DM. Marine mammals and fisheries: the role of science in the culling debate. In: Gales N, Hindell M, Kirkwood R, editors. Marine mammals: fisheries, tourism and management issues. Victoria: CSIRO Publishing; 2003. p. 31-47.

[7] Myers RA, Barrowman NJ, Hutchings JA, Rosenberg AA. Population dynamics of exploited fish stocks at low population levels. Science 1995;269:1106-8.

[8] Mohn R, Bowen WD. Grey seal predation on the Eastern Scotian Shelf: modelling the impact on Atlantic cod. Canadian Journal of Fisheries and Aquatic Sciences 1996;53:2722-38.

[9] Punt AE, Butterworth DS. The effects of future consumption by the Cape fur seal on catches and catch rates of the cape hakes. 4. Modelling the biological interaction between Cape fur seals Arctocephalus pusillus pusillus and the cape hakes Merluccius capensis and $M$ paradoxus. South African Journal of Marine Science (Suid-Afrikaanse Tydskrif Vir Seewetenskap) 1995;16: 255-85.

[10] Yodzis P. Must top predators be culled for the sake of fisheries? Trends in Ecology and Evolution 2001;16:78-84.

[11] McLaren I, Brault S, Harwood J, Vardy D. Report of the Eminent Panel on Seal Management. Department of Fisheries and Oceans Canada, 2001. Retrieved from http://www.dfo-mpo.gc.ca/seal-phoque/reports-rapports/mgtplan- plangest001/EPSMGEGP_e.pdfS.

[12] Yodzis P. Culling predators to protect fisheries: a case of accumulating uncertainties. Response from Yodzis. Trends in Ecology and Evolution 2001;16:282-3.

[13] Gulland J. The impacts of seals on fisheries. Marine Policy 1987;11:196-204.

[14] Montevecchi WA. Introduction. In: Montevecchi WA, editor. Studies of high-latitude seabirds. 4. Trophic relationships and energetics of endotherms in cold ocean systems. Occasional Paper 91. Ottawa: Canadian Wildlife Service; 1996. p. 7-9. 
[15] Moen T. Reflections on the Narrative Research Approach. International Journal of Qualitative Methods 2006;5(4):2-11. Retrieved from /http://www.ualberta.ca/ iiqm/backissues/5_4/pdf/moen.pdfS.

[16] Frank AW. Why study people's stories? The dialogical ethics of narrative analysis. International Journal of Qualitative Methods 2002.;1(1):1-20.

[17] Oppenheim AN. Questionnaire design, interviewing and attitude measurement. London: Pinter Publishers; 1992.

[18] Ritchie J, Spencer E. Qualitative data analysis for applied policy research. In: A Bryman A, Burgess RG, editors. Analysing qualitative data. London: Routledge; 1994. p. 173-94.

[19] Comiskey P. Bord lascaigh Mhara. Personal communication. Dublin, 19 June 2007.

[20] Jentoft S. Fisheries co-management as empowerment. Marine Policy 2005;29:1-7.

[21] Woodlock J. Nobody asked me. Marine Times. October 2007. Retrieved from /http://www.marinetimes.ie/Assets/_archive_2007/1007_news_07.htmIS.

[22] Carroll L. Through the looking-glass: and what Alice found there. Macmillan Children's Books; 1998.

[23] Wilde O. The soul of man under socialism. In: De Profundis and Other Writings. London: Penguin Books; 1986. p. 19-53.

[24] Lane MB, McDonald G. Community-based environmental planning: operational dilemmas, planning principles and possible remedies. Journal of Environmental Planning and Management 2005;48:709-31. 